\title{
DEMINUTIIVID IDAPOOLSETE LÄÄNEMERESOOME RAHVASTE ANIMISTLIKUS KEELEKASUTUSES ${ }^{1}$
}

\author{
MADIS ARUKASK, EVA SAAR
}

Annotatsioon. Idapoolsete läänemeresoome rahvaste maailmapilt ning eluviis on tihedalt seotud looduskeskkonna ja vastavate uskumustega ning moderniseerumine on nende puhul alanud märksa hiljem. Kultuurilises võrdluses ja keelelise käitumise pragmaatikast lähtudes võib tõdeda, et tihedas loodusseoses elavate põlisrahvaste suhtluspraktikates ning eneseväljenduses on emotsioonid ja isiklik hinnangulisus küllaltki tagaplaanil, sellel on aga usundilised põhjused. Artiklis uuritakse idapoolsemate läänemeresoome rahvaste (eriti vepslaste) keelekasutuse eripära animistlikust aspektist. Ennekõike keskendutakse deminutiividele, mida neis keeltes esineb võrreldes muude läänemeresoome keeltega tunduvalt rohkem. Deminutiivide külluslikul kasutamisel peab neis keeltes olema mingi muu põhjuslikkus kui tänapäeval kõikjal domineeriv antropotsentriline hinnangulisus. Oma välitöökogemustele tuginedes analüüsime animistliku deminutiivse keelekasutuse tagamaid ja põhjuslikkust.

Võtmesõnad: animism, antropoloogiline keeleteadus, kõnelemise etnograafia, läänemeresoome keeled, pragmaatika, usund ja keel

\section{Sissejuhatus}

Olles mitmeid aastaid vepslaste ja teiste läänemeresoome rahvaste seas välitöid teinud, nendega ühist eluruumi jaganud ning osa saanud nii nende keelelisest kui ka uskumuslikust maailmapildist, hakkavad paratamatult silma torkama teatud üksikasjad, mis kameraalsel korpusetekstide lugemisel või sõnaraamatute lehitsemisel samamoodi kohale ei jõua. Kui inimeste kõnelemist ja tegutsemist ümbritseb tihedam kontekst, mida

${ }^{1}$ Uurimistööd on finantseerinud Eesti Teadusagentuur (PUT 670) ning hõimurahvaste programm. 
uurija saab vahetult jälgida ja kogeda, omandab aines teise värvingu. Kui keeleainese ja konteksti koosmõju on pikaajalisem - nagu see juhtub vähegi tõsisemalt võetavatel välitöödel -, hakkavad settima kvalitatiivselt teist sorti arusaamad uuritava inimrühma maailmapildi ja keelekasutuse seostest. Selliste tunnetuslikult tajutavate ning olemuslikult kõnekate seikade kasvõi oletuslik mõista ja selgitada püüdmine aitab edasi liikuda ka muude keelte mõistmisel ning loomulikult pakub teiste keelte aines ka rikastavaid paralleele, selgitusi ja taipamisi.

Selle artikli teemaks on deminutiivide kasutamise põhjuslikkus eri rahvastel, ennekõike aga idapoolsematel läänemeresoomlastel. Nagu öeldud, tõukub see teema vepslaste, aga ka lüüdide ja karjalaste ning isurite, vadjalaste, setude ja teiste lõunaeestlaste juures läbi viidud välitöödest ning isiklikest kogemustest pikema aja jooksul. Põhjaeestilise eesti ühiskeele kõnelejale ei saa märkamata jääda, et keeliti on deminutiivide kasutustihedus nii läänemeresoome kui ka teistel rahvastel omajagu erinev. Et me mõlemad oleme ühe vanema kaudu võrumaist päritolu ning meil on seetõttu kokkupuude lõunaeesti keelega varasest lapsepõlvest olemas, tuleneb erinevuse tajumine esmajoones eesti keele kahe väga erineva põhikuju tundmisest ja tajumisest. Tõepoolest, võru (aga ka setu või mulgi) keeles on deminutiivide kasutamine igapäevaselt (olnud) tunduvalt ulatuslikum kui põhjaeestlastel, kus deminutiivsust esineb kas juba kivistunud (leksikaliseerunud) rudimentidena või siis tähistab nende kasutamine üsna sihiteadlikku ettevõtmist kellegi või millegi spetsiaalseks (rõhutatud) kiitmiseks, meelitamiseks, hellitamiseks jne. Viimasel juhul on deminutiivsetel vormidel selgelt teadvustatud tähendus ja funktsioon. Neile vastanduvad keeled, kus deminutiivid näivad paiguti olevat otsekui teadvustamata kõnevoo loomulik osa, ehkki päris sajaprotsendiliselt see ei tarvitse nii olla.

Deminutiivide ulatuslikumaid kasutusjälgi (põhja)eesti keeles võib leida keeleajaloolistes kihistustes, mis tähendab, et ka siin on olnud deminutiivide kasutussfäär varem mingil põhjusel laialdasem ${ }^{2}$. Väga palju deminutiive leidub eesti regilauludes (ning ka muudes folklooritekstides), mis viitab sellele, et eri allkeeltes ja/või žanrides on eesmärgist ja funktsioonist tulenevalt keelekasutuslikud vahendid küllaltki erinevad, sealhulgas mitte üksnes poeetilistel, vaid ehk enamgi veel usundilistel ja

2 Eesti keele teadusliku grammatika (EKG I: 501) järgi on tänapäeva eesti keeles kaks deminutiivsufiksit: $-u$ ja $-k e(n e)$. 
sellega seotud suhtlusstrateegilistel põhjustel. Niisiis tuleb deminutiivide uurimisel silmas pidada ka allkeelte ressursse, mis võivad olla seotud erinevate taotluste, suhtlusstrateegiate, rühmade ning nende uskumustega. Kõnelemise etnograafiline uurimine (kitsamas mõttes alates Hymes 1962) juhatab meid palju laiemale väljale, kaugemale meile arvatavalt tuttavast, justkui iseenesestmõistetavast maailmapildist, eemale sellepõhise tajumise ja seletamise ainuvõimalikkusest.

Idapoolsemate läänemeresoomlaste (eriti vepslaste, karjalaste) traditsiooniline maailmapilt erineb tuntavalt viimase pooleteisesaja aasta jooksul üsna äkilise muutuse läbi teinud eestlaste maailmapildist. Moderniseerumine ja rahvuslik emantsipeerumine tõid eesti kultuuris kaasa suuri muutusi usundilises tunnetuses ning uskumustes, samuti suhetes igapäevase elukeskkonnaga (resp. loodusega ${ }^{3}$ ). Kadunud vana maailmapilti võisid suhteliselt paremini hoomata veel saja aasta eest tegutsenud või sündinud eesti keele- ja rahvaluuleteadlased, kuid mitte enam tänased uurijad või inimesed üldse. Arhailisem maailmatunnetus, mida seostame animistliku metsakultuuri ning kogukondliku, sealhulgas ka erinevaid usundilisi sfääre ühendava kollektiivsusega, võis eestlastel muutuma hakata paiguti veelgi varem, olles mõjutatud keskkonna eripärast ning ajaloolistest, kõrgreligioossetest ja olmelistest eriarengutest ${ }^{4}$, milles keskset osa on mänginud pikemaajalisem lääneliku kultuuriruumi serval asumine.

Eeldame, et see kõik puudutab ka siin vaadeldavat kitsamat teemat deminutiive, nende kasutussfääri ja selle tagamaid. Me liigume antropotsentrilise või valdavalt inimestevahelise keelekasutuse ringist animistlikku ontoloogiasse, milles inimene oma praktikatega ei ole mitte kõiksuse kese, vaid selle osa. Sellise maailmapildi vahetumat tundmaõppimist on meile võimaldanud iseäranis välitööd Kesk-Vepsa külastutes Venemaa Leningradi ja Vologda oblastis ning vähemal määral ka uurimiskäigud teiste läänemeresoome rahvaste juurde. Loomulikult tõdeme siin, et pole põhjust kõnelda läänemeresoome rahvaste maailmapildist ja olemisviisist

3 Seda võiks märgistada ka n-ö kultuurkeelte eeskujul eesti keelde leiutatud looduse sõna ja kontseptsioon ise, mille abil inimkeskne maailm ja selle väline sfäär või vastand nüüd lõpuks diskursiivselt eristati.

4 Eesti mõtteloos oli tõenäoliselt üheks selliseks perioodiks Liivi ja Põhjasõja vaheline nn Rootsi aeg, periood, mil sõjavapustustega käis kaasas vana külakatoliikliku maailmapildi väljajuurimine luterluse poolt, uusaegse maailmapildi sissetung, riigipoliitika hüplikkus jm. Selle aja idealiseerimine on pigem retrospektiivne tegevus. 
(ontoloogiast) kui läbinisti vaid animistlikust. Arusaadavalt on rahvaid sajandite jooksul vähem või rohkem mõjutanud eluviisi järkjärgulised muutused, kristliku maailmavaate lisandumine ning viimaks ikkagi ka üldisem moderniseerumine. Siiski pole kõik see tegelikust, elatavast tunnetusest ja toimimisest varasemaid kihistusi täielikult välja tõrjunud.

\section{Deminutiivide funktsionaalne mitmekesisus ning selle tagamaad}

Deminutiivide funktsioonid maailma keeltes on mitmekesised, väljendades ennekõike suurust (väiksust), hellitavat suhtumist (kiindumust), viisakust ja heasoovlikkust, hüpokoristlikkust (pehmendavat-lepitavat suhtumist), aga ka pejoratiivsust (halvendamist) või hoopis augmentatiivsust (algse omaduse või tähenduse suurendamist/paisutamist). Selle suhtelise mitmekesisuse juures on aga ilmne nende funktsioon võtta mingist positsioonist lähtuv seisukoht, kus „kõneleja subjektiivne hinnang antakse edasi erinevate alussõnast lähtuvate morfoloogiliste teisenduste abil“" (Martín Calvo 2020: 84). Hinnangu andmine keeleliste vahenditega hõlmab nii semantilisi (väiksus/suurus, umbkaudsus, tähtsusetus, intensiivsuse kasv jms) kui ka pragmaatilisi tunnuseid (nõrgenemine, imetlemine, hellitamine, tagasihoidlikkus jms). See on väga harilik keeltevaheline tunnusjoon, mis avaldub lapsekeeles ning keele omandamisega seotud tähelepanekutes (Prieto 2005: 65), ja loomulikult mitte ainult seal. Deminutiive kasutades positsioneerib inimene end kas tahtlikult või ka teadvustamatult kellegi või millegi suhtes.

Deminutiivsusega võib mitmetes maailma keeltes väljendada ka sugu. Eesti keeles, kus grammatilise soo kategooria puudub, saab seda teatud juhtudel väljendada just deminutiivsufiksiga (temake).

Paljudes keeltes ei tarvitse deminutiividel ilmtingimata olla (enam) mingit selgelt tajutavat funktsiooni. Semantiliselt tühjadena on deminutiivid võrdsed alussõnaga. Niimoodi on leksikaliseerunud suurem osa deminutiividest eesti keeles. Deminutiivide tuhmumisele osutab seegi, et paljudel juhtudel ei ole tuletise alussõna enam iseseisvana keeles tarvitusel ning selle tähendus ei ole enam selgelt läbipaistev, nt eesti keeles pääsuke, siisike, väike, tilluke, natuke, äike, päike (vrd nt eLõ päiv, mille tähendus on nii 'päev' kui ka 'päike' > pääväkene 'päevake; päikseke'). Nii ongi paljud kunagised deminutiivid deminutiivsuse minetanud ja kasutusel tähenduselt neutraalsena. Näiteks, et moodustada deminutiivi 
sõnast pääsuke, on kaks võimalust: 1) lisada veel üks deminutiivsufiks (pääsuke $+k e(n e) \rightarrow$ pääsukesekene), seejuures võiks eesti keeles sufiksite jada olla ka lõputu: pääsukese(kese)kene; 2) kasutada desufiksatsiooni ehk eemaldada sõnast viimane formaalne deminutiivsufiks (pääsuke $\rightarrow$ pääsu). Desufiksatsioon on Petar Kehayovi ja Rogier Bloklandi (2007: 98-99) hinnangul deminutiivide moodustamisel soome keeles märksa harilikum kui eesti keeles.

Deminutiivsust võib peale sufiksiaalse tuletuse väljendada ka muude keeleliste vahenditega. Eesti keeles kuuluvad siia kahtlemata analüütilised konstruktsioonid, nagu kulla ema, kuku laps, mida saab omade sõnavaraliste vahenditega moodustada igas läänemeresoome keeles, aga ka muud sünteetilised sõnamoodustusviisid. Koondtermini mittesufiksaalne deminutiivituletus all on eesti näitel uuritud deminutiivse $i$-hääliku sisestamist tüvesse (nt mees $\rightarrow$ mehike ${ }^{5}$, kapp 'puunõu' $\rightarrow$ kipp 'kibu'), omastavavormi leksikaliseerumist ( $p$ oeg $\rightarrow$ poja 'pojake', vend $\rightarrow$ veñna 'vennake') ja deminutiivset geminatsiooni (ema $\rightarrow$ ĕmme, isa $\rightarrow$ išsi) (Kehayov, Blokland 2007). Deminutiivne geminatsioon on eriti omane just laste- ja hoidjakeelele, seda nii eesti kui ka soome keeles, nt sm hevonen $\rightarrow$ heppa 'hobune', silmä $\rightarrow$ simmu 'silm' (VISK § 206), aga ka lõunaeesti keeles, nt silm $\rightarrow$ tsiḿm: aig om tśimmäk̆kese? vallalõ laškó ' 'on aeg silmakesed lahti teha' (SESS).

Deminutiivsust väljendatakse paljudes keeltes ka mittemorfoloogiliste vahenditega. Maailma toonikeeltes saab deminutiivsust edasi anda näiteks tooni abil (vt nt Jurafsky 1996: 539), eesti ja lõunaeesti keeles saab deminutiivsuse väljendajaks olla pelgalt palatalisatsioon ${ }^{6}$, sageli esineb see koos $u$-deminutiiviga, nt ee käsi $\rightarrow k \ddot{a} \check{t}^{\prime} t^{\prime} u, k \tilde{o} h t \rightarrow k \tilde{o} \check{t}^{\prime} t^{\prime} u, k u \breve{t}^{\prime} s u$, not'śu (Kasik 2015: 241); eLõ kul'l'a 'kulla, armas'.

Keeled on pidevas muutumises, nõnda ka keelte morfoloogiline vara, mis allub keele häälikuloolise arengu seaduspärasustele. Nii on aja jooksul muutunud ka läänemeresoome deminutiivsufiksite häälikuline koosseis. Samas võivad aja jooksul muutuda ka deminutiivsufiksite roll ja funktsioon. Deminutiivafiksid kuuluvad adjektiivimoodustajate ja

5 Mõnel juhul jääb küsimus, kas tuletis sisaldab interfiksi $i$ või on see sõnavormi häälikuloolise kujunemise tulemus, nt GenSg *meehe- $n+U t+k$ Ainen $>$ *mēhütkäinen >> mehike (vt Kehayov, Blokland 2007: 94).

6 Näiteks Lauri Kettunen (1962: 118-124) eristab eesti keeles peale regressiivse ja progressiivse palatalisatsiooni ka deminutiivset palatalisatsiooni. 
nominaliseerijate kõrval maailma keeltes kõige kergemini laenatavate afiksite hulka (Gardani jt 2015: 9; Seifart 2020). Sellele, et deminutiivsufiksid on liikuv keeleline vara, st kergesti laenatav element, on juhtinud tähelepanu ka Lembit Vaba (2004), uurides eesti perekonnanimistusse kuuluvaid nimesid, mis sisaldavad võimalikku läti deminutiivset järelliidet.

Välitööd vepslaste, aga ka lüüdide ja karjalaste juures on näidanud, et vene keele pikaajaline mõju on kontaktkeeltes tuntav. Kindlasti mõjutab neid keeli ka deminutiivide rohkus vene keeles. Deminutiivsete vormide laenamisel on mitmeid mooduseid. Koos toorlaenuga võetakse üle vormiline deminutiivsus, asendades vene sufiksi vepsa omaga:

vn короб-ка > vps korobe-ine : korobe-iže-n 'karp/karbike' (GS, Päžar, Vologda oblast, 2017)

Silmatorkavad on ka juhud, kus vene deminutiivsufiksitele liidetakse omakeelne (siinses näites vepsa) deminutiivsufiks - võimalik, et vene deminutiivi pole hellitavana tajutud, või siis on tegemist mingi muu huvipakkuva tähendusnüansi lisamisega:

vn девочка 'tüdruk' > vps devotška-ine

vn девушка 'neiu' > vps devuška-ińe, nt devuškaińe ištub ulitsal 'neiukene istub tänaval (õues)' (AR, Voilaht, Vologda oblast, 2014)

Läänemeresoome keelte deminutiivsust ja deminutiivide moodustust on kõigele vaatamata vähe uuritud. Enamasti on kirjeldatud deminutiive sõnamoodustuse ja tuletussüsteemi vaatenurgast ja nende osana (vt nt Kasik 2004, 2015 ja sealsed viited; Neetar 1990; Vare 1981, 1994). Mägiste (1928, 1929) on käsitlenud konkreetseid tuletussufikseid, Kehayov ja Blokland (2007) on vaadelnud eesti keele mittesufiksaalset deminutiivituletust, Kupp-Sazonov (2019) on võrrelnud eesti ja vene keele deminutiivsufiksite kasutust Anton Tšehhovi teoste tõlgete näitel. Ent seni puudub laiem evalueeriva morfoloogia (mh deminutiivide) ning deminutiivide funktsioonide ja deminutiivsuse rolli käsitlus nii eesti kui ka läänemeresoome keelte kohta. Kuna valdkond on väga lai, vääriks see mitut monograafiat. 


\section{Deminutiivid läänemeresoome areaali usundilises keelekasutuses}

Kerkib küsimus, kas deminutiivide semantiline laenamine keelest keelde tähendab automaatselt ka pragmaatilise poole laenamist. Võiks eeldada, et viimane on esimesest mõnevõrra autonoomsem, enam seotud rahva või inimrühma igapäevase eluolu, kultuuritüübi, maailmapildi, uskumuste ja praktikatega. Kui eeldada deminutiivide massilist laenamist slaavi-balti keeltest läänemeresoome keeltesse, siis tuleks küsida, miks on eri keeled selles olukorras strateegiliselt erinevalt käitunud.

Vaadeldes meile teadaolevate andmete valguses ning oma kogemuste põhjal läänemeresoome keeleruumi, saame välja tuua iseloomulikke üldteadmisi deminutiivide kasutamise kohta. Üldisemalt võttes eristuvad selgesti ida- ja põhjapoolsemad karjala, lüüdi ning vepsa keel, kus deminutiivide kasutamine igapäevases kõnes on pigem tavaline. Ingerimaa keeled (vadja, isuri, ingerisoome) on deminutiivide esinemise poolest tunduvalt tagasihoidlikumad. Soome (ilma meiepoolse süüvimiseta) ning (põhja)eesti on samuti deminutiivivaesed keeled. Seevastu lõunaeesti keeles kasutatakse neid rikkalikumalt, nagu ka sissejuhatuses juttu oli.

Liivi keeles kohtame deminutiive samuti vähe. Selles on oma osa kindlasti häälikuloolistel aspektidel, nagu sise- ja lõpukadu, millega nii mõnegi sufiksi häälikuline koosseis on pea miinimumini viidud. Sellegipoolest ei puudu deminutiivsus seal täielikult. Kuivõrd on liivi deminutiivsus seotud läti keele mõjuga, me siin hinnata ei oska. Läti keelt on võrreldes leedu keele või slaavi keeltega hinnatud pigem deminutiivivaese(ma)ks, samas Skandinaavia keeltega võrreldes rikkamaks (RūķeDravina 1953: 452).

Kaasaegsest eesti perspektiivist võiks deminutiivsust pidada justkui mitteläänemeresoomelikuks jooneks, millekski, mis tuleneb pigem võõrmõjust (vene, balti) ning on seega sporaadiline. Ilmsesti see nii päriselt ei ole. Selle vastu kõnelevad nii ajaloolised tõigad kui ka eespool antud põgus ülevaade, mille järgi pole pikaajaline asumine vene keele kontakttsoonis (eriti vadjalaste, isurite puhul) deminutiivide ulatuslikumat kasutamist kaasa toonud. Rahvaluules, näiteks läänemeresoome rahvaste vanemate laulude keeles, on deminutiivsus samas kõikjal vägagi levinud. Kuigi meil pole põhjust välistada eriarengut keeliti, oleks siiski praktiline püüda otsida esmalt mingeid süsteemsemaid seletusvõimalusi. Et meie välitöökogemused on pannud meid üha enam tähelepanu pöörama 
inimeste maailmapildile, siis võiks püüda jälgida mingeid uskumuste ja usundiga seotud mustreid, seda nii rahvausu kui ka kõrgreligioosses kontekstis.

Inimene ei ole justnagu autonoomselt eksisteeriva keele küljes olev „kandja“, nagu võib kameraalses uurimistöös lihtsasti tunduda, vaid keel sidestab inimest ümbritseva kõiksusega mitmekülgselt: inimene peegeldab maailma, suhtleb maailmaga ning seob ennast maailmaga keele vahendeid kasutades. Inimene on keele keskel, seda mitte kitsa antropotsentrilise mudeli, vaid üldisemas funktsionaalses mõttes. Keelega tehtavate tegude tagamaad on ühiskondlikud, sotsiolingvistilised, tegelikult aga veelgi laiemad. Iseäranis traditsioonilistes kultuurides ületavad nad tavamaailma piire ning püüdlevad tunnetuslikult transtsendentse poole. Keelelisi vahendeid kasutades suheldakse muude olenditega, loomade, lindude, paikade ja objektidega, surnute ning üleloomulike ilmingutega.

Tundub, et suhteliselt lühike, mõnesaja aasta pikkune valgustusajast alanud epohh on peamiselt lääne ühiskonnas keelelise suhtluse adressaate ja registreid palju muutnud, õigemini kahandanud. Veel uusajal on üleloomulike olendite kõnetamisviisid ja -praktikad olnud tavalised (hädavajalikud) ka läänekristluses (eksortsismis loomulikult ka nüüd, vrd Valk 1994: 149-153), rahvakultuuris on nad aga säilinud tänaseni ning küllap saamas uut hingamist seoses uusvaimsete praktikate ja esoteerika pealetulvaga tänapäeva inimeste elus. Nähtamatu maailma või ka iseendaga valjuhäälne kõnelemine on uuemal ajal lükatud ebanormaalsuse sfääri ning stigmatiseeritud võimalusel meditsiiniliste diagnoosidega, kuigi see pole olnud ebanormaalsus mujal, ei ajas ega ruumis.

Kui heita pilk eri (põlis)rahvaste mitmekesisesse traditsioonilisse maailmanägemise ja -kajastamise võimalikkusse, avaneb meie ees pilt, mis on kõike muud kui antropotsentriline. Selliste animistlike ontoloogiate dokumenteeringud vaatavad meile vastu väga paljudest välitööpõhistest antropoloogilistest (sealhulgas keele-) uuringutest maailma eri kohtadest ning nende põhjal loodud kontseptsioonidest inimese arusaama kohta teda ümbritsevast - sellest, mille keskel ta kogu aeg viibib ning millega ta peab end võimalike vahendite abil suhestama.

Maailm, milles tegutsevad nii inimlikud kui ka mitteinimlikud olendid, on inimpärane selles mõttes, et ka muudele (vaim)olenditele ja lindudele-loomadele omistatakse siin omadusi, mis on võrreldavad või otseselt pärit inimesele arusaadavatest kujutlustest. Juba klassikaks 
saanud perspektivismi kontseptsioon, mille arendas välja Lõuna-Ameerika põliselanike maailmapildi ja uskumuste põhjal Eduardo Viveiros de Castro (1998), näitab, et ka loomade ühiskond on põlisrahvaste uskumuste kohaselt organiseeritud sarnaselt inimeste omaga (perekonniti, sugukonniti jne). Enamgi veel, ka loomad on siis, kui inimene neid ei näe, inimsarnased ning kõnelevad omavahel inimkeeles. Loomadena heiastuvad nad vaid inimsilmale. Laialt levinud totemistlikud uskumused, mis seovad inimese ja mingi loomaliigi sugulussuhetesse (inimene on loomset päritolu, tootemloom on ta esivanem), tõestavad, et traditsioonilistes ettekujutustes pole inimese ja looma vahel pidanud mingit liigipiiri olemagi, või siis on see rituaalides ja muudes piiripealsetes olukordades kergesti ületatav. Soomeugri rahvaste karutotemismi on kõige enam dokumenteeritud hantidel ja mansidel (vt nt Lintrop 2007), kuid jälgi sellest leidub ka Karjalas (vrd Konkka 2014), küllap vepslastelgi (Vinokurova 2006: 105-117).

Totemistlikus maailmas on inimene olnud enam sugulane oma tootemi kui näiteks teise klanni või rahva esindajaga. Paljude rahvaste etnonüümides, milles sisaldub enesekohane ,inimese“ või „tõelise inimese“ semantika, peegeldab see enda eristamist nii teistest rahvastest kui ka teistest olenditest, mis mõlemad paiknevad samaväärsel distantsil. Seda, et maailmapilt ei ole organiseerunud ja jagunenud meile tänapäeval käepäraste arusaamade, kategooriate ja taksonoomiate järgi, peegeldavad uurimused, mille kohaselt ei tarvitse ka surmajärgne teispoolsus olla inimese jaoks nii põhimõtteline eristusjoon, küll aga on võõras ja hädaohtlik hoopis ka „siinilmas“ varitsevate deemonlike olendite klass.

Küttimisega tegelevates kultuurides on elementaarne mõista kogu elu jahipidamise ja ärasöömise mudeli kaudu. Tšuktšide uskumuste kohaselt on näiteks kõigel kehaliselt olemasoleval elu ('hing' = 'keha' (uvi'rit)). Kehalise „nähtamatu“ poole, eluandva printsiibina on olemas va'irgin ('olemine, eksistents') ning selle n-ö nähtav pool on unatgirgin ('elu'). Kui pärisinimene (või muu pärisolend) sureb, siis ta on tegelikult edasi „elus“, oodates taassündi. Kõik kehaline vajab süüa, kogu elusus kujutab endast pidevat jahipidamist erinevate olendite vahel. Pärisolendite maailmale vastandub siinilmas tannit - muu, võõras, mitteinimlik või „mittepäris“ ohtliku ilma esindaja, kes või mis võib pärisinimliku anastada, üle võtta, ära süüa. Selle väga konkreetseks avalduseks on koletislikud kannibalid (ke'let), kes võivad peituda igas tundmatus olendis. Nad tuleb ära tunda, nende eest end amulettide ja muuga kaitsta, et inimesest ei saaks nende 
poolt ära õgitud ohver ning ta ei muutuks seeläbi ise ke'let'iks. Selleks muutumisega on seotud ,tegelik surm“ kui ärasöödud saamine - väljumine $u v i$ 'rit-olemisest, mille esindajaid on kõiksuses olemas konstantne piiratud hulk (Lykkegård, Willerslev 2016). Mõistame selle näite abil hästi, kui erinev (limiteeritud) võib antropotsentriline maailmapilt olla pärimuskultuurilisega võrreldes.

Vepsa rahvakultuuris väärib tähelepanu inimliku ja vaimude ilma piiridel liikumise ja üleloomulike olendite (mh deminutiivse) kõnetamisega seoses karjuste ja teadjate tegevus. Mõlemad rollid on vaimselt piiripealsed, omamoodi mitteinimlikud või pühad selle sõna laiemas arhailises tähenduses (vrd Anttonen 1992). Nad osalevad karjatusperioodi eel maagilise lepingu sõlmimises metsavaimuga, misjärel hakkavad karjusele kehtima erilised kokkulepitud keelud, mis muudavad ta käitumise ja konditsiooni tavamõttes poolinimlikuks, mis ei kajastu aga üksnes ta edasises tegevuses (eraldi hoidmine ja distants tavainimlikust), vaid ka keelekasutuses (napisõnalisus; vt Arukask 2016). Karjus on karjatamisperioodil omamoodi väravavalvur inimliku ja vaimude ilma piiril, nendevahelise balansi garanteerija, selle eest vastutaja - et külakari maagilise lepingu rikkumise läbi otsa ei saaks ning metsavaim oma kiskjad koduloomadest eemal hoiaks.

Vaimudega suhtlemine ning sellele iseloomulik keelekasutus pole võõras ka ühelegi tavavepslasele. Selle kõige ilmekamaks tunnistajaks on paigavaimude poole pöördumisel kasutatavad palveloitsud. Neid läheb vaja vaimude hallatavasse sfääri sisenemisel: kalavetele saabudes, metsa minnes, ka võõrasse kohta ööbima sattudes, et pöörduda sealsete majahaldjate poole. Sellised lühikesed vormellikud pöördumised algavad alati vaimude perekonna deminutiivse kõnetamisega, nagu näiteks selles tekstis, mis on mõeldud kasutamiseks enese sisseseadmisel võõras elukohas:

Ižandaižed, emagaižed, dedaižed, babaižed, lapsuded, velĺluded, sõzaruzed, primkad tide kanzha mid, minun lapsid, pidagat kui ičetoi, (neljad čogaišt kummardade).

[Isandakesed, emandakesed, taadikesed, eidekesed, lapsekesed, vennakesed, õekesed, võtke enda perre meid, minu lapsi, hoidke kui endi omi, (ja nelja nurgakese poole kummardada).]

(VL, Kurb, Leningradi oblast, 2008)

Traditsiooniliste kultuuride ontoloogiline keerukus vaatab meile vastu ka muus läänemeresoome vanemas (aga alati mitte veel kadunud) 
rahvakultuuris. Arusaam, et see maailm ei piirdu antropotsentrilise inimsfääriga, on tuttav igas rahvausus ning tuleb esile ka eesti usundilistes muistendites või üleloomulikuga seotud kogemuslugudes. Viimaseid kõnelevad inimesed ka tänapäeval, mitte ainult meelelahutuseks, ning nende lõppemist pole mõtet ennustada. Keelekasutuses on üleloomuliku suhte peegeldajaks ja osaks tabusõnad, samuti eriliselt kodeeritud kõne või vaikuse kasutamine kriitilistes situatsioonides ning mitmesugused muudki kõneteod (vt ka Arukask, Saar 2020).

\section{Võimalikud kõrgreligioossed mõjud ning itkud ja loitsud}

Läänemeresoome kultuuri- ja keeleruum jaguneb erinevate kõrgreligioossete uskkondade vahel, seetõttu on põhjust silmas pidada ka selle võimalikku mõju eri rahvaste uskumustega seotud keelekasutusele, siinkohal ka seoses deminutiivsusega. Esmapilgul näikse, et luterliku superstraadiga rahvakultuurid (eesti, soome) on deminutiivivaesed, õigeuskliku superstraadiga aga mitte. Siin aga hakkavad jällegi ühelt poolt eristuma vadja ja isuri ning teisalt lõunaeesti. On kindlasti seaduspärane, et protestantlik religioossus ning sellest vähem või rohkem mõjutatud inimeste maailmapilt on teispoolsuse (eriti surmajärgsuse) suhtes õigeusklikust erineval positsioonil. Luterlikus teoloogias puudub surmajärgset vaheala tähistava iseseisva sfääri kontseptsioon, milles eriti katoliikliku õpetuse järgi puhastatakse lahkunute hingi piinarikkas tules. Pole võimatu, et just luterliku teoloogia mõjul on ladina purgatooriumist etümologiseerunud eesti põrgu (vt ka Oja, Soosaar 2013 ja sealsed viited), mis katoliikluses aga sünonüümid (samad usundilised lookused) loomulikult ei ole. Õigeusk purgatooriumit otseselt ei käsitle, kuid on lahkunu hinge surmajärgse saatusega seoses nii õpetuslikult kui ka mälestamispraktikates protestantismist tunduvalt tegusam.

Reformeeritud kristluse argumendid purgatooriumi ja muu surmajärgse vähesel käsitlemisel tegelikus usupraktikas põhinevad seisukohal, et sellekohased veenvad tõestused puuduvad pühakirjas ning pole seega relevantsed. Puhastustuld ,kuradi pettusena“ ründas juba Martin Luther (LU 2014: 182). Seeläbi on selge joonega tõmmatud piir ametliku usu ja selleteemaliste rahvausuliste uskumuste ja praktikate vahele. Kahtlemata on esivanemate kultus ning sellega seotud rikkalik matuse- ja surmajärgne kombestik midagi olemuslikult väga algupärast, mille on luterlus aga 
suures osas tagaplaanile või päris välja tõrjunud. Õigeusklikud rahvakultuurid panustavad lahkunute mälestamisele mitu korda rohkem energiat ja tähelepanu, rikkalikumad on ka vastavad tavad ja kombed - need on selles mõttes tõelised mälestamiskultuurid.

Surma- ja mälestamisrituaalide keskne sõnaline folkloorižanr on itk, mis protestantlikus rahvakultuuris on teatavasti kadunud, välja tõrjutud, kuid mis eksisteerib (või on viimase ajani eksisteerinud) kõikjal õigeusklike läänemeresoome rahvaste hulgas. See ürgne žanr ja praktika pole ajalooliste andmete kohaselt tundmatu olnud ka näiteks eestlastel (millest annavad tunnistust kasvõi Läti Henriku teated) ning on kadunud tõenäoliselt alles viimaste sajandite jooksul. $\mathrm{N}$-ö erandina kuuluvad itkukultuuride hulka ka Ingerimaa (luterlikud) soomlased (nende itkukultuurist vt eriti Nenola-Kallio 1982). See erandlikkus tuleneb aga ilmselt vadja-isuri areaalsest mõjust (ibid.: 14; Laanest 1997: 4) või veelgi enam nende rahvaste osalisest kultuurilisest substraadist, mis on ümberrahvastumise käigus saanud osaks kohalikust soomlusest.

Itkužanr on sarnaselt kohalike runolauludega (või ka regilauludega põhjaeesti ruumis) neid allkeeli, kus Ingerimaa rahvastel tuleb deminutiive ohtramalt ette (see kehtib loomulikult itkude kohta üldisemalt, ka muudel rahvastel). Seda võib seletada kas antropotsentrilises või animistlikus võtmes. Esimesel juhul oleks tegemist lahkunud kalli inimesega, kes igavesti leinaja südames edasi elab ning kelle suhtes on esikohal inimlikud isiklikud emotsioonid. Teisel juhul oleks tegemist kadunute klassi ümberkategoriseerunud või rituaali käigus ümberkategoriseeritava olendiga, kellega seoses hakkab kehtima mingi muu suhtenorm, mis on seotud muu hulgas surnuhirmu, tõrjemaagia, kunagi kindlasti ka totemistlike esivanemauskumustega ${ }^{7}$. Lihtsustatult öeldes oleks itkudes kadunukese deminutiivne kõnetamine samastatav või sarnane loomse maailma esindajate deminutiivse kõnetamisega, meile kõige käepärasemalt siis jahindusega seotud eufemismides (nt ee *karvoi > karu, eLõ virrui 'hunt' (SESS)). Samuti avaldub see kindla võtte kasutamises vaimolendite puhul, lähtudes näiteks uskumusest, et surnu on teatud tingimustel saanud

${ }^{7}$ Kraasna maarahva kombeid, uskumusi ja ka kõnetegusid kirjeldades on seda omal ajal suurepäraselt tabanud näiteks Oskar Kallas, öeldes: „Surmaga lõppeb ainult kehalik olemine; hing elab pärast keha suremist veel edasi. Hinged võivad järelejäänud omakstele kahju ja kasu saata; neid kardetakse ja katsutakse neid lepitada, nende poole õhatakse, et nad oma abi ei keelaks“ (Kallas 1903: 91). 
muutuda paiga- või majavaimuks (vrd Paulson 1997 [1966]: 108-113; Loorits 1990 [1948]: 52-54).

Arvestades itkude pigem kollektiivset funktsionaalsust ning arhailisi surnute kogukondlikkusega seotud uskumusi üldisemalt, on animistlik seletusviis siin kahtlemata asjakohasem või vähemalt ajaloolises plaanis ulatuslikum. Itkude funktsioon ja itkeja tegevus on (lisaks isiklikule emotsionaalsele aspektile) olnud ühiskondlik, antropotsentrilise maailma (kui seda minevikus kitsas mõttes üldse eeldada) piire ületav, ühtlasi rituaalis neid piire ka tõrjemaagilistel eesmärkidel taasuuendav. Isiklik lein hägustus suure tõenäosusega nende laiemate (olulisemate) funktsioonide sisse. Liiatigi ei saanud suhe lahkunu(te) ja ärasaatja(te) vahel olla arusaadavatel põhjustel alati ühtemoodi inimlikult lähedane või ,positiivne“, itketud on aga kohustuslikult ühtemoodi kõiki lahkunuid (nt Konkka 1985: 33). Nii seletub vormellik itkukeelne deminutiivide kasutamine ${ }^{8}$ nii läänemeresoome rahvastel kui ka teistel pigem animistliku maailmavaate ajaloolise domineerimisega.

Animistliku ja antropotsentrilise maailmapildi põkkumist võib silmas pidada ka muude poeetiliste deminutiivirohkete folkloorižanrite vaatlusel. Sellekohastesse näidetesse ülearu süüvimata täheldagem üldiselt, et deminutiive tuleb läänemeresoome rahvastel ette regulaarselt loitsudes, nii regivormilistes kui ka rahvusvahelisemates proosaloitsudes (historioolades). Kui itkude puhul võis deminutiivi kasutamisel veel oletada inimlikku lähedust kõnetatavaga, siis ei saa sellest väga juttu olla näiteks sellistes loitsudes, kus on vaja mõjutada pahategijat, et ta tekitatud kahju elimineerida. Eestigi ussisõnades nimetatakse madu näiteks Leenakeseks (eufemism + deminutiiv; vt Rüütel 1994: 31), millel ei ole suuremat pistmist hellitava deminutiivsusega. Loits žanrina on sageli agressiivne, ründav, maagiliselt ärategev. Seega on siin tegemist pigem strateegiaga, mida rahvapäraselt nimetatakse kiitmiseks (vt ka Oinas 1984: 218-219; Arukask, Saar 2020: 100-101). Kiitmise eesmärk on olnud maagiline kahjutegemine, sellekohaste näidete hulk on pärimustekstides suur. Deminutiivil on siin n-ö maagiliselt pehmendav/lahtistav efekt, et saavutada eelist, ülekaalu, mõjuvõimu vaenlase, konkurendi või muu kahjustatava üle.

Historioolades esineb deminutiive seoses üleloomulike vaimolenditega, kelle ülesandeks on üleloomulikus ruumis korda saata otsustav

8 Deminutiivsust kategooriana on vepsa ja karjala itkudes ka mõnevõrra käsitletud (vt Stepanova 1985: 131-132; Žukova 2015: 110-113). 
akt või aidata kaasa selle õnnestumisele. Proosaloitsus võivad selles osas esineda nii kristlikku päritolu kui ka loodusvaimudena identifitseeritavad tegelaskujud. Ühes meie poolt 2008. aastal Leningradi oblastis Nemži külastus salvestatud vepsa hambaloitsus kõneldakse näiteks kaheteistkümnest tsaarikesest tsaarinnakestega, kelle osalusel toimub loitsus otsustav sündmus - murdub halja nurme keskel seisva kuldse kuuse (maailmapuu) oks, millest voolab välja vaik. Analoogiamaagia loogika kohaselt lastakse loitsus vaigu valgumisega kaduda (hajuda) ka teadja juurde tulnud patsiendi hambavalu.

Deminutiivne kood on ilmne ka enamikul läänemeresoome rahvastel levinud regi-/runolaulutraditsioonis, millel ei peaks animistliku usundililise maailmaga justkui otsest tegemist olema. Nn Kalevala-kood (vt nt Kuusi, Tedre 1979) seob meid aga ikkagi aastatuhandetetaguse maailmapildiga, mille vormelikeel on (kasvõi konserveerivalt) lauludes meieni toonud. Regilaulude üksikasjalisem vaatlus aga ei mahu selle artikli sisse ning vääriks eraldi käsitlusi. Tõenäoliselt leiaksime sealt aga nii eespool nimetatud maagilist kiitmist (peremees-peremehike jne) kui ka animistlikku või lihtinimlikku sõnakasutust (emakene-hellakene jne), mis võivad omavahel seguneda, ning kindlasti palju muudki mõtlemist väärivat.

Deminutiivide pragmaatika diakroonilise muutumise võimalikkust folklooris on oluline silmas pidada eriti pikemaealisemate žanride puhul, samuti seoses uskumuste ja nende muutumisega. Nii näiteks võib lapsega seotud deminutiivsus lisaks hoidjakeelsele registrile seletuda usundilise piiripealsusega. Sarnaselt lahkunuga (eesti keeles kadunukene), kelle hing on 40-päevase perioodi jooksul (sõltuvalt kultuuriruumist võib see aeg ka erineda) olnud seotud veel siinpoolsuse ja tuttavate kohtadega, on ka vastsündinud laps mõnede uskumuste kohaselt olnud sama perioodi jooksul seotud surnute ilmaga ${ }^{9}$, asunud veel liminaalses üleminekufaasis (vt mitmeid näiteid van Gennep 1960: 50-64). Seega on tegemist olnud piiripealse anomaalse olendiga, kelle sünd inimesena ühiskondlikus mõttes seisis alles ees.

9 Kristlikus kultuuris ei toimu tavaolukorras ka lapse ristimist enne selle perioodi lõppu, samuti mitte varrusid. Sama perioodi jooksul peetakse sünnitanud naist traditsiooniliselt veel roojaseks. 


\section{Deminutiivid animistliku maailmapildi peegeldajana}

Deminutiivide (tegelikult enamiku keeleliste nähtuste) senisel käsitlemisel on lähtutud antropotsentrilisest mudelist. Selle järgi on keelt tarvis inimestevaheliseks kommunikatsiooniks, keelelise väljendumise adressaat, algus ja ots on inimene. Seega peegeldavad ka deminutiivide funktsioonid ja taksonoomia ennekõike antropotsentrilist mõtlemisviisi, ühtlasi tulenevad need sellest. Deminutiivid on keele see osa, mille kaudu antropotsentrilises mudelis väljendatakse väga palju emotsionaalsust. Deminutiive kasutades antakse edasi sellealast hinnangulisust, väljendatakse oma tundeid, on need siis positiivsed või negatiivsed. Antropotsentriline tunnetus ei tähenda, et deminutiivse adresseerituse või refereerituse objektiks peab olema ainult inimene. See võib loomulikult olla mistahes nähtus, olend, asi, mille inimene deminutiivi appi võttes oma tunnetusilma haarab, „määratleb“.

Animistliku ontoloogia oluline iseärasus - nagu meie seda kogenud oleme ja mõistame - on selles, et isikliku emotsionaalse poole väljendamise, hinnangute andmise ja seeläbi enese positsioneerimisega ollakse ääretult ettevaatlikud. Oleks õigem öelda, et paljudes traditsioonilistes kultuurides selline register pigem puudub: emotsionaalsust, intiimsust jms väljendatakse kas väga kitsastes usalduslikes piirides või on see silmnähtavalt ritualiseeritud või kollektiivselt reeglistatud. Sellist suhtluskoodi esindavad paljud maailma põlisrahvad, meile lähematest küttimise ja põdrakasvatusega tegelevad põhjarahvad, samuti animistliku metsamiljööga tihedas kokkupuutes olnud või olevad parasvöötme vööndi rahvad, kelle hulka kuuluvad ka (idapoolsemad) läänemeresoomlased (vt ka Arukask, Saar 2020).

Emotsioonide varjamine ning vastavate lingvistiliste või ekstralingvistiliste aktide puudumine või vähene esinemine on seotud eelkirjeldatud animistliku maailmapildiga, milles enese ohtuseadmine inimvälise vaimude maailma suhtes on suuremaid vigu. Väljenduslik vabadus, enese emotsionaalne representeerimine, hinnangute vaba väljendamine jms argiolukordades on tõepoolest omane pigem sekulaarsematele ja individualistlikumatele kultuuridele ja keeltele, ennemini läänes (resp. moderniseerunud kultuurides) kui idas (resp. traditsioonilisemates kultuurides). Esimeste hulka kuulub pigem ka vene keel oma üldkasutataval kujul linlikus, suurrahvalikult domineerivas miljöös. Vene kõnekeele kõrgendatud emotsionaalsusele on ka spetsiaalselt tähelepanu juhitud (Voronina 
2012: 15; Holodionova, Rõženko 2019), ja Venemaa põlisrahvaste esindajad pigem irduvad sellest koodist, jäädes suletuks, sõnaahtraks, vaikivaks, „rumalaks“. On tähelepandav, et need jooned ei kao suhtlusest kiiresti ka siis, kui vahetuvad eluviis ja miljöö, näiteks seoses kiire linnastumise ja traditsiooniliste elatusviiside taandumisega 20. sajandil (vepslaste kohta vrd nt Siragusa 2018: 53-55).

Läänemeresoomelik traditsiooniline kultuuritaust on selles osas küllap hästi tuttav ka eestlastele. Veel 18.-19. sajandil on saksa kirikuõpetajad õpetanud eesti talupoegadele viisipärase suhtlemise nüansse. Heasoovlik Redik Willem Willmann (1793: 95) annab oma „Ellamisse-Juhhatajas“ sellist nõu: Kui sa woora tuppa tulled, ja olled terretanud, siis ärra seisa mitte, kui olleksid sinna keleto. Monnel on se wiis nenda, kes woera jures olles ei lausu sanna mitte enne, kui neilt küssitakse: mis sa tahhad, ehk mis sa rägid? Eesti talurahvast kujutab vaimselt endassetõmbununa (valdavalt flegmaatilisena, näoilmelt loiu, tuimana) 19. sajandi alguses ka Karl Ernst von Baer (1976 [1814]: 29-30) ning me ei pea teda süüdistama pahatahtlikkuses, vaid pigem tunnustama tema etnograafilist täpsust. Veel nüüdki võib angloameerika viisakusvestlemine ning sund täita vaikus kõnelemisega tekitada eestlases probleeme.

Kui aga deminutiivirikkus on inimkeskse (sh emotsiooniküllase) maailmapeegelduse silmapaistev osa, paneb selline positsioon meid küsima deminutiivse keelekasutuse ulatuslikkuse tagamaade kohta näiteks vepslastel või lü̈̈didel. Kui maailma emotsionaalne, isiklikest tunnetest või afektidest lähtuv peegeldamine pole kultuuris iseloomulik, vaid vastupidi - on ebasoovitatav või lausa ohtlik, peavad sellel olema mingid muud seletused.

Vaadeldes deminutiivivaest põhjaeesti keelt, võime märgata, et üks teemavaldkond, milles tänapäeva eesti kirjakeelde kivistunud deminutiivid esinevad, on seostatav vana usundilise maailmapildiga. On alust arvata, et sellised sõnad nagu päike 'päev ${ }_{[\mathrm{dem}]}$, äike 'suur ja ürgne uskumusolend ${ }_{[\mathrm{dem}]}$ ', pääsuke 'loomismüüdi maailmaloomisega seotud $\operatorname{lind}_{[\mathrm{dem}]}$, aga ka interjektsioonid taevake või jumaluke annavad edasi pigem usundilist maailmavaadet, mis võib olla seotud ka viljakusmaagia ja heaoluga, mitte ei väljenda individualistlikku, isiklikult heakskiitvat positsiooni (,päike on hea, sest tema käes on hea päevitada“). Aegadetagust suuremat deminutiivide kasutamist peegeldavad ilmselt ka mõned tänapäeva määrsõnad, nagu nt sõna *öö $+-(i) n e n$ 'öö ${ }_{[\mathrm{dem}]}$ ' temporaalses 
funktsioonis kasutatavad (ajaloolised) allatiivi-, instruktiivi-, translatiivijm vormid: AllSg öösel : InstrSg *öösen > ööse : InstrPl öösi ja öösiti, TrSg ööseks, mis moodustavad paarid samas käändevormis neutraalsete alussõnadega ööl, öiti, ööks (ööse- ja öösi- muid võimalikke päritolu seletusi vt Velsker 2006: 185-186).

Deminutiivide sage esinemine linnunimetustes (lõoke, siisike, värvuke jt) ei ole pidanud tähendama nende hoolivat hellitamist vms, vaid see tuleneb hoopis lindude kui õhuolendite usundilisest ambivalentsusest. Linnud on seotud teise ilmaga, neis on nähtud surnute hingi, nende mõju on võinud olla ka hukutav (vrd linnupete kui tõrjemaagiline söögikord kevadsuvisel ajal). Vormel teele-teele, kurekesed on olnud loitsuosa, mis sai Friedrich Kuhlbarsi abiga lasteluuletuseks märksa hiljem.

Eesti keeles on kõik sellised deminutiivid koos uskumuste taandumisega oma algse sisu kaotanud, neid ei tunnetata enam mingit tähendusvarjundit lisavana, deminutiivsus on üksnes morfoloogiline. Inimeses ei toimu neid sõnu kasutades enam mingit tunnetuslikku nõksatust, mis kunagi võis olla ootuspärane ja mis võis käia koos nende kasutamisega. Deminutiivirikkad keeled sisaldavad ka tunnetuslikult (või emotsionaalse laetuse poolest) väga erineva tasandi näiteid. Vene keeles leidub peale sõnade, kus deminutiivsusel on selgelt kas vähendav, meelitav, halvustav vm funktsioon, ka selliseid, kus igasugune selline tähendusvarjund puudub ${ }^{10}$ või on sellel vaid mingisugune tähendust eristav ülesanne. Vene ручка ('sulepea; käepide'), полка ('riiul') või папка ('mapp; ümbriskaaned') ei väljenda mingit erilist tundelist laetust, äärmisel juhul ehk vaid seda, et need ei ole tingimata (väga) suuremõõtmelised esemed. Маиинка tähendab spetsiifiliselt kirjutusmasinat, eristavalt sõnast машина auto vm masina tähenduses. Скамейка ја скамья vahel võib veel olla mõningane tähendusvarjund, ehkki mõlemad tähistavad pinki ning pigem on kasutusel esimene sõnakuju.

Võiks küsida, kas ei ole deminutiivirohke vepsa või lüüdi keele puhul tegemist sarnase (venemõjulise) olukorraga, kus deminutiivid on sageli muutunud semantiliselt tühjaks. Vepsa deminutiive käsitledes vihjab sellisele sisutusele otseselt Riho Grünthal (2015: 111-113). Siinkohal väärib aga märkimist, et deminutiivide kaudu inimene mitte ainult ei

${ }^{10}$ Sarnaselt eesti sõnaga äike, kus respekteeritavast taevajumalast on saanud tülikas või vaenulik loodusnähtus ning deminutiivsusel pole sellega enam mingit pistmist, vrd setu äio ja äiolanõ 'üleloomulik olend, kurat ${ }_{[\mathrm{dem}]}$ ' (SESS). 
peegelda maailma ega püüa seda mõjutada, vaid ka positsioneerib end maailma asjade suhtes. See positsioneerimine võib olla isekas ja antropotsentriline, aga ka teistsugune. Esimesel juhul on see ootuspärane sellise maailmatunnetuse korral, kus asjad on loodud või välja mõeldud inimese hüvanguks, et tal oleks neist kasu. See on maailm, mille filosoofia väljendub kõnekalt 5. sajandi kreeka filosoofi Protagorase ütluses: kõigi asjade mõõt on inimene. Deminutiivsus on seega siin otsekui mingi (kvaasi)defineeriva funktsiooniga nähtus, mille abil inimene end (ilmselt ka eba- või alateadlikult) maailma asjadega võrdleb või end nende suhtes (või vastupidi) seadistab.

Animistlikus maailmapildis positsioneeritakse end aga oluliselt teisest lähtekohast. Deminutiive kasutades inimene mitte ei kõrvuta ega võrdle end maailma asjadega, ta ei põrku nendega mingitel korrastuslikel või kindlaksmääratavatel eesmärkidel, vaid deminutiivide kasutamise strateegiad on seotud usundilise maailma entiteetidega. Animismis, kus kõik on hingestatud (maailm ei koosne mitte asjadest, vaid elusolenditest), on nende hulk aga tinglikult võttes piiramatu. Suhestuda tuleb kõigega. Mingil moel kõnetama peab kõike, mis inimest tema keskkonnas ümbritseb, igapäevases elus vähemalt seda, mis on tunnetuslikult registreeritav, silmatorkav, mille jaoks on üldjuhul olemas ka sõnad. Otse loomulikult aga ka seda, kes/mis nagunii on juba kategoriseeritav erilise või üleloomulikuna. Seda, mille ambivalentses ohtlikkuses ei ole põhjust hakata katse ja eksituse meetodil ise veenduma - ehk siis vaimolendeid ja ka kitsamalt inimkeskse ja sellest väljapoole jääva maailma mediaatoreid (linnud, tervist või heaolu tagavad või väljendavad asjad jms).

Animistlikule tunnetusele omased nähtamatu või ka pealtnäha vaid füüsiliselt olemasoleva ,asise“ maailma esindajate kõnetamisviisid tulevad eksplitsiitselt esile tavade ja kommete kaudu. Regilaululised looduskõnetused või joiud, aga ka loodusrahvastelt tuttav puudega kõnelemine jõuvarude taastamise või muul eesmärgil (Arukask 2017), milles deminutiivide kasutamine võib olla kesksel kohal, on selle heaks näiteks. Pulmarituaali see etapp, kus pruuti valmistatakse kodust lahkumiseks ette ning ta itkukeeli jätab hüvasti oma kodu ja vanematega, sisaldab deminutiivseid pöördumisi muu hulgas ka kodus ja koduõues olevate erinevate objektide poole (keskvepslaste kohta vrd nt Salve 2000: 251-257).

Keelekasutus, käitumine, suhtumine, kogu olemine muutuvad sellesarnases rituaalses, kuid ka animistlikus argikäitumises sidusaks kultuuriliseks 
tervikuks. Deminutiividel on animistlikus ontoloogias mõneti teistsugune ülesanne kui antropotsentrilises maailmapildis. Otsese peegeldamise kõrval või asemel ennetatakse nende abil väga mitmepalgelise, inimesele sageli otseselt käsiteldamatu või kategoriseerimatu maailma nähtamatuid karisid ja kitsaskohti või libisetakse neist otsekui mööda.

\section{Näiteid välitöödelt}

Loomulikult on deminutiivid ennekõike spontaansele kõnele omane nähtus. Lasta deminutiive demonstratiivselt kasutada või nende kasutamist kuidagi esile kutsuda võiks välitöötingimustes ehk ka võimalik olla, kuid sellelaadsete meetoditega katsetamine pole meie huviväljas olnud. Põhiliselt vestlemegi oma informantidega niisama, suunavate küsimuste abil või siis laseme neil endil kõnelda ja toimetada. Jutukamatelt keelejuhtidelt pole sel moel ainese saamine mingi probleem.

Siintoodud vepsa näidete puhul ongi tegemist selliste olukordadega. Analüüsitav materjal võiks olla muidugi mitmepalgelisem ja mahukam, kuid antud juhul pole probleemiks mitte materjali-, vaid mahupuudus. Illustreerime deminutiivide kasutamise temaatikat mõne näitega, mille seas on jutuajamisi, mis kajastavad nii tundlikumaid teemasid kui ka olmelisemaid olukordi.

(1) Ajasime keelejuhiga juttu ta kodu eeskojas istudes. Tegemist oli kõrgele vanusele vaatamata erksa ja tähelepaneliku inimesega, kellele pakkus meiega suhtlemine huvi. Me ei olnud sel hetkel temaga varem eriti kokku puutunud. Jutt oli üleloomuliku piirimail liikuvast inimesest, teemaks metsas eksimine. Alguses küsisime, mida metsa minnes öelda tuleb, hiljem oli juttu käitumisest, kui ollakse eksinud.

MA: Micced vaihed oma? Kut pidäb pakita?

MT: Ka, pidäb [pakita], mäned ka: ,,voite-ik, voite-ik!“ da, ,, abutagat minei marjaižid kerata!“ da, ,,ougat minunke!“ da, ,,mina tulin tänne tämbei “ da, , kävuka minunke! “da, ningo sanungi. Sid keradangi. Täl vodou griboižid ii_le, suha om näged ka, babukaižid ii_le, griboižid ne. /.../

MA: A konz ristitu mecäs segoib, mis pidäb teha?

MT: Peipašton ka tari, peivašt-ne kacta, miš jot pei om. /.../ Psiveižele kohtha astud dei, tropeine tulob sid dei, tropadme kodihe, mitteine tropaine. En muškande. 
[MA:Millised sõnad on? Kuidas tuleb paluda?

MT: Jaa, peab [paluma], lähed ja: „tere, tere!“ ja, ,aidake mul marjakesi korjata!“ ja, „olge minuga!“ ja, „mina tulin siia täna“ ja, „käige koos minuga!“ ja, niimoodi ütlengi. Siis korjangi. Sel aastal seenekesi ei ole, kuiv on näed ja, (mittelehik)seenekesi ${ }^{11}$ pole, neid seenekesi.

/.../

MA: Aga kui inimene metsas eksib, mida siis peab tegema?

MT: Tarvis on päikesepaistet, seda päiksekest vaadata, et kus päike on. /.../ Päikesekese suunas astud ja, teekene siis tuleb ja, teed mööda [lähed] koju, sellisekene teekene. Nüüd ma enam ei hakka mäletama [igaks juhuks].]

(MT, Päžar, Vologda oblast, 2014)

Selles näites võib märgata, et deminutiivsed on metsast saadavad, metsa sfääri kuuluvad saadused (marjad-seened). Küttidel ja korilastel pole saagi ja saaduste hankimine kunagi pelgalt mehaaniline töö, vaid omamoodi spirituaalne akt, dialoogiline protsess teispoolsusega (vrd Ingold 2000: 61-76), mille juurde kuuluvad kõik ettenähtud rituaalid ning ettevaatusabinõud. Metsasaadused pole ,pärit" siinpoolsusest, vaid kellegi „teise“ meelevallast ja nende hankimisel (ning neist kõnelemisel) peetakse seda silmas. Näite teises pooles on kätte jõudnud kriisiolukord, mis tähendab seda, et metsa kaetuse ${ }^{12}$ alt välja pääsemiseks on eriti olulised päike ja teerada. Loomulikult ei hakata neist deminutiivselt kõnelema alles eksimisel, vaid see on üleüldine kood. Usundiliselt tundlikule teemale osutab ka selle lõigu lõpp. Keelejuht väljendab siin, et ta rohkem (edasi) sellest asjast ei mäleta. Tegemist on n-ö tahtliku mittemäletamisega, mida usundilistel teemadel vesteldes sageli ette tuleb - informant saab ühel hetkel justkui aru, et neil teemadel ei ole vaja palju lobiseda, eriti võõrama inimesega.

(2) See vestlus leidis aset keelejuhi kodus, kus ta köögilaua ääres jutustab oma kasinast igapäevaelust ja toimetulekust. Olime juba pikemaajalised tuttavad ning tal polnud põhjust või vajadust meie eest midagi varjata. Meie kohtumised rõõmustasid teda alati.

11 Vepsa keeles tehakse põhisõnavaras vahet kahel põhilisel seeneklassil: lehikseened (seń või venepäraselt grib) ning mittelehikseened (babuk).

${ }^{12}$ Läänemeresoome metsarahvaste seas levinud uskumus (sm metsänpeitto), mille kohaselt võib eksinu-kadunu olla vaimolendite poolt kaetatud nii, et ta jääb otsijatele nähtamatuks, olles samas ise suutmatu olulisi kohti ja metsast väljapääsu teed ära tundma. 
Louk, tänämbei hlebnõi pвi, mänen loukha, ostan leibäd dei nižušst ostan vouktad dei ningomaižed buhankeižed on, a batonad ni kut en tahto_en, en ostlegi, ni kut en tahto, en tahto_en. Ningomad peńed buhankeižed, ostan mogoman, pehmeine, sen radan da voi-se, en tahto voita ka majonezou voidudan sidä minä śön.

\section{/.../}

Pjatnacat tõsjatš penzijad ka hvatib śöndha da minei śöndha sada hvatib, oukha hougoišt, i kamu abutan, necile, vunukale opendaha ka tõsjača rublei andan kaikučel kul. Vnutška bezrabotnõi ištub Vidlas,

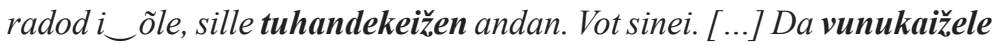
tuhandekeižen andan.

[Pood, täna on leivapäev, lähen poodi, ostan leiba ja ostan valget nisusaiakest ja sellisekesed pätsikesed on, aga batooni ei taha mitte kuidagi, ei ostagi, mitte kuidagi ei taha, ei taha mitte. Sellised väiksed pätsikesed, ostan sellise, pehmekene, selle teen ja see või, ei taha võida (määrida) ja majoneesiga määrin, seda ma söön.

/.../

Viisteist tuhat pensionit piisab söögiks, mulle söönuks saada piisab, halukesteks (küttepuudeks) ka, ja keda(gi) [veel] aitan, neile, lapselapsele kooli jaoks ka tuhat rubla annan igal kuul. Lapselapseke istub tööta Vidlas, tööd ei ole, sellele tuhandekese annan. Vot sulle. [...] Ja lapselapsekesele tuhandekese annan.]

(MA, Ladv, Leningradi oblast, 2016)

Siin on tegemist argisema teemaga, mis kuulub siiski eaka inimese jaoks n-ö ellujäämistemaatika hulka. Deminutiivselt käib jutt poest saadavast meelissaiast, samuti eluliselt üliolulisest pensionirahast ning küttepuudest. Eks Venemaal on tavainimese jaoks ka riiklik struktuur ja võimusüsteemid ,mütoloogilised“ asjad ning nendepoolsed hüved on pärit omamoodi üleloomulikust sfäärist. Inimliku läheduse mõttes on deminutiivne ka lapselaps (kasutatud vene внук-tüve). Esimesel mainimisel on seejuures kasutatud venekeelset sõna (naissoost, ühtlasi deminutiivset komponenti sisaldav внучка), teisel juhul vepsa deminutiivi.

(3) Olime Pondalas külas korraga mitmel inimesel, kes kõik teadsid väga palju huvitavat ja tavatsesid uurijate meelehärmiks läbisegi kõnelda. Jutuks oli kariloomade pidamine nii kolhoosiajal kui ka enne seda, karjused ja nende töö, kohustused, karjatamisega seotud maagilised keelud-tabud jms. Siin toodud näites küsitakse, kuidas viis karjus läbi karja maagilist piiramist (vepsa ümbärduz) - olulist rituaali karja kevadisel väljalaskmisel, kus kokku kogutud karja ümber käidi loitse või palveid 
lugedes maagiliste esemetega. Sellele võis eelneda ka muid tähtsaid tegevusi, näiteks metsast sipelgapesadest mätaste toomist karjateele, arvatavalt analoogiamaagia põhimõttel - et kari hoiaks kogu suve kokku nagu sipelgad pesas ning loomi kaotsi ei läheks.

MA: A hän tezi kut pidab teha ümbardust?

TS: A ümbärduz om, hö, muražnoitta todaz, murahaižid todaz, tanhaižele vedaz, živataižen kons pästaškatas ka kaikid proittaz, jumalaižil kaikid kogoižil pandaz $i$ kaikid proittaz, siga sanutaz kut necižil vaihil što bõ naku midä tehda i tol'ka takim putjom $i$ ratihe.

[MA: Aga tema teadis, kuidas tuleb teha ümbardust?

TS: Aga ümbärduz on, nemad (loomad), sipelgate abil piirata tuuakse, sipelgakesi tuuakse, karjatanumakesele viiakse, kui loomakest välja laskma hakatakse, siis kõigist käiakse ümberringi, kogu karjakesega pannakse ja kõigist käiakse ikoonikestega ümberringi, seal öeldakse kuidagi sellisekeste sõnadega, et seal kohas [st karjas olles] mida teha ja ainult sellisel moel tehtigi.]

(TS, Pondal, Vologda oblast, 2014)

Kariloomade pidamine on vepslastel olnud eluliselt tähtis tegevus ning nii külakogukonna kui ka hiljem nõukogude ühismajandite karja hoidmisel oli elukutseliste karjuste maagilistel oskustel suur kaal. Karjatamine ei toimunud mitte kultuurkarjamaadel, vaid metsakarjamaadel, seetõttu oli kogu maagia kese suunatud inimsfäärist välja, metsavaimuga lepingu sõlmimisele ning sellest kinni pidamisele. Loomad anti kogu karjaajaks metsavaimu meelevalda. See võiks põhjendada ka seda, miks selles näites on deminutiivsed nii loomad ja kari kui ka maagilised vahendid (karjateele puistatavad sipelgad, ikoonid, maagiline sõnakasutus).

(4) Erinevalt eelnenud näidetest toimus järgnev jutuajamine meesinformandiga, ehk siis deminutiivide kasutamine ei ole vaid naiste pärusmaa. Kõneleja on Šonadalal sündinud ja seal kogu elu elanud. Deminutiivid hakkasid kuhjuma eriti siis, kui jutt läks kena Uk-oja kaldal mäe otsas asuvale külakabelile (časovneińe časovnikeińe) ning sellega seotud muudele objektidele (tee, oja, mägi). Näis, nagu liiguks kõnelev mees mõtetes ise mööda maastikku kabeli suunas ja selle ümbruses, millega koos muutus kohe ka ta positsioon.

IA: A tam vot on Mägijärv dorogaińe sigä, hän ii_amu tehtud, mogomputeińe tehtud časovnikeižno. A tam ranše sigä oli no, svjatoje mesto.

Sigä rutšeińe jokseb, oja.

MA: Ojaińe. 
IA: Ka. Vot necel ojou oli svjatoje mesto. A puteižen tegiba sinnei mägudele sid', mäguden libud $i$ sid' na praava. A se oja nazõvaješja Uk-oja.

MA: Uk-oja?

IA: Uk-oja. Daa.

MA: A nece svjatoje mesta, mis siga tehliba edu?

IA: No ranše vod, pedronpei vot praznik nece, / . . / käveliba sinne nece čassonikeižno, ojale. Külbliba siga.

[IA: Aga vot seal on Mägjärve teekene seal, see on hiljuti tehtud, selline rajakene oli tehtud tsässonakese juurde. Aga varem oli seal püha paik. Seal jookseb ojakene. Oja.

MA: Ojake.

IA: Jaa. Vot selle oja juures oli püha koht. Aga [nad] tegid rajakese sinna mäekesele siin, mäekesele lähed üles ja siis paremale. Aga selle oja nimi on Uk-oja.

MA: Uk-oja?

IA: Uk-oja. Jaa.

MA: Aga mis seal pühas paigas ennemalt tehti?

IA: No vot varem, vot selle küla püha oli pedropäev, /.../ käisid sinna tsässonakese juurde, oja äärde, kümblesid seal.]

(IA, Šondal, Leningradi oblast, 2016)

(5) Sama mehe puhul köitis tähelepanu ka see, et deminutiivide järgi otsustades (vrd näites sõnade pert' 'maja' ja pert'eine 'maja $\mathrm{a}_{\text {dem] }}$ ' kasutamist) näis kadunud vanematekodu talle armsam (olulisem, püham?) kui see maja, mille ta oli ise koos vennaga ehitanud ja kus ta on sõjaväest tulekust saadik hiljem elanud.

Nece pert' minun vellegke tehtud. /.../ Minä läksin armija necest pertišt, udes, udest pertišt. /.../ A edu meid'en raditelski pert'eine naku oli, kuz traktor seižub, vot sid' oli pert'eine. A sigä oli dvoroiné, se meid'en dvor jo uz tehtud om.

[See maja on mu vennaga ehitatud. /.../ ma läksin sõjaväkke sellest majast, uuest, uuest majast. /.../ Aga vanasti meie vanemate majakene oli sealsamas, kus traktor seisab, vot seal oli majakene. Aga seal oli majapidamisekene, see meie majapidamine on juba uus tehtud.]

(IA, Šondal, Leningradi oblast, 2016)

Selle näite võib muidugi lugeda ka isikliku inimliku meeleliigutuse valda kuuluvaks, millel ei tarvitse animistliku üleloomulikkusega sidet olla. Kuigi vepslastel on ka elamud üleloomulike majavaimudega asustatud, ei saa me kõigele vaatamata puhtinimlikku (antropotsentristlikku) mõõdet 
täielikult välistada. Nii nagu sai ka sissejuhatuses tõdetud, ei ole meil traditsioonilise läänemeresoome kultuuritüübi puhul põhjust kõnelda vaid läbinisti animistlikust ilmavaatest, kuigi oleme veendunud selle domineerimises vähemalt idapoolsematel rahvastel.

\section{Kokkuvõte}

Siin artiklis esitatud põhiargument on, et vepsa ning ka teiste idapoolsemate läänemeresoome keelte deminutiivirohkus on seotud ennekõike animistliku, mitte antropotsentrilise ontoloogiaga. Selle järgi ei saa inimene, kelle uskumuslik maailmapilt on kaugelt laiem, kui vaid inimkeskne suhteliselt sekulaarne haare seda tavapäraselt käsitleb, lähtuda maailma kajastamisel üksnes isiklikust hinnangulisusest ja emotsionaalsusest. Vepslased ja Karjala põlisrahvad on suurema osa oma etnogeneesist veetnud metsamiljöös ning viibivad selles keskkonnas osaliselt ka tänapäeval. Nende uskumustes ja tunnetuses on praeguseni suur osa hõivatud nähtamatu vaimude maailma esindajatega, seda nii metsas kui ka kalavetel (üldse „looduses“), aga ka inimsfääris - nii võõrastes paikades kui ka oma kodus.

Siin esitatud seisukohad põhinevad järgmistel argumentidel.

1. Kui deminutiivsus (või vähemalt deminutiivsuse käsitlemine) eri keeltes on seostatav valdavalt personaalse hinnangulisuse ja ka inimliku emotsionaalsusega, siis mis saab olla deminutiivide funktsioon neis keeltes, kus animistlik maailmapilt ei sea neid omadusi käitumises ja väljenduslikkuses esikohale, vaid hoopis vastupidi - väldib või surub neid igapäevaelus tagaplaanile? Deminutiivne keelekasutus peab siin järelikult põhinema millelgi muul ja seda olulisel määral.

2. Meie arvamust toetab isiklik kogemuslikkus välitöödel vepsa külades viibides ning vepslaste kõnetegusid reaalses tegevuses jälgides. Pole kahtlust, et nii vanema kui ka keskmise põlvkonna vepsa keelejuhtide jaoks on animistlik maailmapilt endiselt tegelik tunnetatav reaalsus.

Sellel, mis meile deminutiivide kasutuses mõtestuks emotsionaalse väljenduslikkuse, hinnangulisuse või kasvõi viisakusena, peab animistlikus ontoloogias olema mingi teine funktsioon. Argine emotsionaalsus on animismis tugevalt tabuline, moodne viisakus kategooriana aga suhteliselt uus asi, seda vähemalt idapoolsetel läänemeresoomlastel, kelle tihedam 
kokkupuude modernse maailmaga on paremal juhul sajakonna aasta vanune, paiguti aga veelgi hilisem. Meile tänapäeval viisakuse mõttes elementaarsed kõneteod (nagu tänamine või komplimentide tegemine) on varem olnud negatiivse märgiga, mõtestunud maagiliselt ohtu seadvate või otseselt kahjustavate praktikatena. Ettenähtud viisakust on kahtlemata esinenud ka traditsioonilises kombestikus, kuid seal on see olnud peamiselt rituaalne (ehk emotsionaalses mõttes tühi).

Eeldame oma kogemusele tuginedes, et deminutiivide kasutamine on idapoolsematel läänemeresoome rahvastel seotud animistliku maailmavaatega, seega pigem ettevaatlikkusega kui hinnangulisuse ja emotsionaalsusega. Deminutiivide abil väljendatakse respekti ja tähelepanelikkust, mille adressaat on inimväline maailm. Deminutiivid ei ole siin antropotsentrilise enesekesksuse teenistuses. Nad on seotud ellujäämisstrateegiaga, seda aga hoopis teisest perspektiivist. Animistlik keelekasutus on vaadeldavatel rahvastel säilinud ka hoolimata eluviisi ja kultuuritüübi paratamatust muutumisest. Nii nagu kultuuris, eksisteerib ka keelekasutuses teatud inerts. See tähendab, et varasemast maailmapildist pärit nähtused ei tarvitse kaduda üleöö, isegi mitte siis, kui uus maailmapilt või moevoolud end hoolega peale suruvad. Animistliku keelekasutuse jäljed püsivad aga kaua nii kõnelemise etnograafias, morfoloogias kui ka muudes keele koostisosades.

\section{Kirjandus}

Anttonen, Veikko 1992. „Püha“ mõiste rahvausundi uurimises. - Akadeemia $12,2514-2535$.

Arukask, Madis 2016. Vepsa-põhjavene karjusekultuur - rollid, tabud ja seksuaalsus parasvöötme metsavööndi traditsioonilises ühiskonnas. Uurimusi vepsa rahvausust. (= Sator 16. Artikleid usundi- ja kombeloost.) Toim. Madis Arukask. Tartu: Eesti Kirjandusmuuseumi Teaduskirjastus, 13-88. http://dx.doi.org/10.7592/Sator.2016.16.arukask

Arukask, Madis 2017. Animistlik kõnelemine puudega kahe läänemeresoome näite põhjal. - Keele kõrgendikud. Pühendusteos professor Birute Klaas-Langi 60. sünnipäevaks. (= Eesti ja soome-ugri keeleteaduse ajakiri 8 (1).) Toim. Kristiina Praakli, Tõnu Tender, Valter Lang. Tartu: Tartu Ülikooli Kirjastus, 21-39. http://dx.doi.org/10.12697/jeful.2017.8.1.02

Arukask, Madis, Eva Saar 2020. Vaikimine, rääkimine ja muud traditsioonilised kõneteod vepsa rahvakultuuris kultuuridevahelises võrdluses. - Mäetagused 77, 89-116. http://dx.doi.org/10.7592/MT2020.77.arukask_saar 
Baer, Karl Ernst von 1976 [1814]. Eestlaste endeemilistest haigustest. (= Loomingu Raamatukogu 33.) Tallinn: Perioodika.

EKG I = Mati Erelt, Reet Kasik, Helle Metslang, Henno Rajandi, Kristiina Ross, Henn Saari, Kaja Tael, Silvi Vare 1995. Eesti keele grammatika I. Morfoloogia, sõnamoodustus. Tallinn: Eesti Keele Instituut.

Gardani, Francesco, Peter Arkadiev, Nino Amiridze 2015. Borrowed morphology: An overview. - Borrowed Morphology. Ed. by Francesco Gardani, Peter Arkadiev, Nino Amiridze. (= Language Contact and Bilingualism 8.) Berlin, Boston, Munich: Walter de Gruyter, 1-23.

Gennep, Arnold van 1960. The Rites of Passage. Chicago: University of Chicago Press.

Grünthal, Riho 2015. Vepsän kielioppi. (= Apuneuvoja suomalais-ugrilaisten kielten opintoja varten XVII.) Helsinki: Suomalais-Ugrilainen Seura.

Holodionova, Rõženko 2019 = Светлана Ипполитовна Холодионова, Юрий Александрович Рыженко 2019. Языковая эмоциональность как культурологический феномен. - Гуманитарные и социальные науки. https://cyberleninka.ru/article/n/yazykovaya-emotsionalnost-kakkulturologicheskiy-fenomen (29.01.2021).

Hymes, Dell 1962. The ethnography of speaking. - Anthropology and Human Behavior. Ed. by Thomas Gladwin, William C. Sturtevant. Washington: Anthropological Society of Washington, 13-53.

Ingold, Tim 2000. The Perception of the Environment. Essays on Livelihood, Dwelling and Skill. London, New York: Routledge.

Jurafsky, Daniel 1996. Universal tendencies in the semantics of the diminutive. - Language 72 (3), 533-578.

Kallas, Oskar 1903. Kraasna maarahvas. Helsingi: Soome Kirjanduse Seltsi trükikoda.

Kasik, Reet 2004. Eesti keele sõnatuletus. Tartu: Tartu Ülikooli Kirjastus.

Kasik, Reet 2015. Sõnamoodustus. (= Eesti keele varamu I.) Tartu: Tartu Ülikooli Kirjastus.

Kehayov, Petar, Rogier Blokland 2007. Mittesufiksaalne deminutiivituletus eesti keeles. - Emakeele Seltsi aastaraamat 52. Peatoim. Mati Erelt. Emakeele Selts. Tallinn: Teaduste Akadeemia Kirjastus, 87-124.

Kettunen, Lauri 1962. Eestin kielen äännehistoria. Kolmas Painos. (= Suomalaisen Kirjallisuuden Seuran toimituksia 156.) Helsinki: Suomalaisen Kirjallisuuden Seura.

Konkka 2014 = Алексей Петрович Конкка 2014. О культе медведя и «медвежьем карсикко» в финско-карельском пограничье. - Финноугорские языки и культуры в социокультурном ландшафте России. Материалы V Всероссийской конференции финно-угроведов. Петрозаводск, 25-28 июня 2014 г. Петрозаводск: Карельский научный центр РАН, 229-232. 
Konkka, Unelma 1985. Ikuinen ikävä: karjalaiset riitti-itkut. Helsinki: Suomalaisen Kirjallisuuden Seura.

Kupp-Sazonov, Sirje 2019. Deminutiivsete noomenite funktsionaalsusest vene ja eesti keeles mõningate Tšehhovi jutustuste ning nende tõlgete näitel. Lähivõrdlusi. Lähivertailuja 29. Peatoim. Annekatrin Kaivapalu. Tallinn: Eesti Rakenduslingvistika Ühing, 113-140. http://dx.doi.org/10.5128/ LV29.04

Kuusi, Matti, Ülo Tedre 1979. Regivärsilise ja kalevalamõõdulise laulutraditsiooni vahekorrast. Dialoog üle lahe. - Keel ja Kirjandus 2, 70-78.

Laanest, Arvo 1997. Isuri keele Hevaha murde sõnastik. Tallinn: Eesti Keele Instituut.

Lintrop, Aado 2007. Vana traditsioon, noored esitajad. - Mäetagused 35, 7-26. http://dx.doi.org/10.7592/MT2007.35.lintrop

Loorits, Oskar 1990 [1948]. Eesti rahvausundi maailmavaade. Tallinn: Perioodika.

LU 2014 = Luterlikud usutunnistuskirjad, 2014. (= EELK Usuteaduse Instituudi õppekirjandus 11.) Tartu, Tallinn: SA Ajaleht Eesti Kirik, EELK Usuteaduse Instituut.

Lykkegård, Jeanette, Rane Willerslev 2016. Regenerating life in the face of predation: A study of mortuary ritual as sacrifice among the Siberian Chukchi. - Sibirica: Interdisciplinary Journal of Siberian Studies 15 (2), 1-39. https://doi.org/10.3167/sib.2016.150201

Martín Calvo, Rafael 2020. Evaluative derivatives and evaluative forms: Two distinct groups of affixed lexical units in evaluative morphology. - Bridging Languages and Cultures II. Linguistics, Translation Studies and Intercultural Communication. Ed. by Guntars Dreijers, Jānis Sīlis, Silga Sviḳe, Jānis Veckrācis. Berlin: Frank \& Timme, 83-112. http://dx.doi. org/10.13140/RG.2.2.35871.92326

Mägiste, Julius 1928. oi-, ẹi-deminutiivid läänemeresoome keelis. Läänemeresoome nominaaltuletus. I. (= Acta et Commentationes Universitatis Tartuensis (Dorpatensis) B XII, 2.) Tartu.

Mägiste, Julius 1929. Eesti -ss-aineselisest deminutiivsuffiksist. - Eesti Keel 3-4, 69-75.

Neetar, Helmi 1990. Deverbaalne nominaaltuletus eesti murretes I. Tallinn: Eesti TA Keele ja Kirjanduse Instituut.

Nenola-Kallio, Aili 1982. Studies in Ingrian Laments. (= Folklore Fellows' Communications 234.) Helsinki: Suomalainen Tiedeakatemia.

Oinas, Felix J. 1984. Keskpärasuse apoloogia. - Vargamäe tõde ja õigus. Esseid. Stockholm: Välis-Eesti \& EMP, 215-221.

Oja, Vilja, Sven-Erik Soosaar 2013. Eesti põrgu. - Emakeele Seltsi aastaraamat 58. Peatoim. Mati Erelt. Emakeele Selts. Tallinn: Teaduste Akadeemia Kirjastus, 148-157. https://doi.org/10.3176/esa58.06 
Paulson, Ivar 1997 [1966]. Vana eesti rahvausk. Usundiloolisi esseid. Tartu: Ilmamaa.

Prieto, Victor Moisés 2005. Spanish Evaluative Morphology: Pragmatic, Sociolinguistic, and Semantic Issues. Doctoral Thesis. University of Florida. http://etd.fcla.edu/UF/UFE0010940/prieto_v.pdf (08.01.2021).

Rūḳe-Draviṇa, Velta 1953. Adjectival diminutives in Latvian. - The Slavonic and East European Review 31 (77), 452-465.

Rüütel 1994 = Ингрид Рюйтел 1994. Исторические пласты Эстонской народной песни в контексте этнических отношений. (= Ars Musicae Popularis 12.) Таллинн: Академия наук Эстонии.

Salve, Kristi 2000. Kallite kasvatajate juurest võõrale vilule rannale. (Kesk-Vepsa pulmaitkudest). - Tagasipöördumatus. Sõnad ja hääl. Toim. Mare Kõiva, Kristi Salve, Ülo Tedre. Tartu: Eesti Kirjandusmuuseum, 241-264.

Seifart, Frank 2020. AfBo: A World-wide Survey of Affix Borrowing. Leipzig: Max Planck Institute for Evolutionary Anthropology. https://afbo.info/ (29.01.2021).

SESS = Eva Saar, Paul Hagu, Inge Käsi, Maeve Leivo, Hanna Pook, Karl Pajusalu 2020. Seto eripäraste sõnade sõnaraamat. Tartu, Tallinn: EKSA.

Siragusa, Laura 2018. Promoting Heritage Language in Northwest Russia. (= Routledge Studies in Linguistic Anthropology.) New York, London: Routledge.

Stepanova 1985 = Александра Степановна Степанова 1985. Метафорический мир карельских причитаний. Ленинград: Наука.

Žukova 2015 = Ольга Юрьевна Жукова 2015. Вепсские обрядовые причитания: От поэтики жанра к поэтике слова. Петрозаводск: Карельский научный центр РАН.

Vaba, Lembit 2004. „Hellad“ nimed. Ühest lätitaustalisest perekonnanimetüübist. - Emakeele Seltsi aastaraamat 49. Peatoim. Mati Erelt. Tallinn: Emakeele Selts, 50-82.

Valk, Ülo 1994. Kurat Euroopa usundiloos. Sissejuhatus demonoloogiasse. Tallinn: Vikerkaar.

Vare, Silvi 1981. Nimisõnaliited tänapäeva eesti kirjakeeles. Tallinn: Valgus.

Vare, Silvi 1994. Nimi- ja omadussõnatuletus tänapäeva eesti kirjakeeles. (= Dissertationes philologiae estonicae Universitatis Tartuensis 6.) Tartu: Tartu Ülikooli Kirjastus.

Velsker, Eva 2006. Ööd tähistavad ajaväljendid eesti murretes, ühis- ja kirjakeeles. - Emakeele Seltsi aastaraamat 51. Peatoim. Mati Erelt. Emakeele Selts. Tallinn: Emakeele Selts, 184-207.

Vinokurova 2006 = Ирина Юрьевна Винокурова 2006. Животные в традиционном мировоззрении вепсов (опыт реконструкции). Петрозаводск: Издательство ПетрГУ. 
VISK = Auli Hakulinen (päätoim.) 2005. Iso suomen kieliopin verkkoversio [online]. Kotimaisten kielten tutkimuskeskus. https://kaino.kotus.fi/visk/ etusivu.php (29.01.2021).

Viveiros de Castro, Eduardo 1998. Cosmological deixis and Amerindian perspectivism. - The Journal of the Royal Anthropological Institute 4 (3), 469-488. http://dx.doi.org/10.2307/3034157

Voronina 2012 = Людмила Петровна Воронина 2012. Семантика и прагматика деминутивных суффиксов в русском языке. - Вестник Томского государственного университета 359, 15-17.

Willmann, Fr. Willem 1793. Ellamisse-Juhhataja. Ma rahwale heaks üllespantud sest Öppetaiast. Tallinn.

Madis Arukask

Humanitaarteaduste ja kunstide valdkond

Tartu Ülikool

Jakobi 2

51014 Tartu

madis.arukask@ut.ee

Eva Saar

Eesti ja üldkeeleteaduse instituut

Tartu Ülikool

Jakobi 2

51014 Tartu

eva.saar@ut.ee 


\title{
Diminutives in the animistic language use of the eastern Finnic peoples
}

\author{
MADIS ARUKASK, EVA SAAR
}

Diminutives are significantly more used in the languages of the eastern Finnic peoples (Veps, Karelians, Ludians) than others (especially Estonians or Finns). This could be explained by the long-term influence of the Russian language, which is extremely rich in diminutives. However, there are not as many diminutives in Votian or Ingrian, which are no less influenced by Russian. In the analysis of the use of diminutives of both Russian and other languages an anthropocentric perspective dominates. In the linguistic studies, evaluative use of language, courtesy behaviour and expression of emotions have been viewed almost exclusively in terms of human-centred (interpersonal) communication. Our long-term fieldwork has shown that the worldview of the eastern Finnic peoples is still heavily influenced by animistic cognition of nature and corresponding beliefs and linked to related behavioural practices and speech acts. The peoples of northern Eurasia, whose worldview is dominated by animistic ontology, are characterized by relatively restrained, non-emotional self-expression, which has to do with caution about the world of spirits. People do not talk about their feelings and plans; they also avoid giving assessments, making compliments, and praising others. Diminutives, as a phenomenon generally related to assessments and emotions, must have another function here. Based on our experience, we assume that this is related to an animistic worldview, leaning toward caution rather than an overflow of emotion. Diminutives express respect and attentiveness, which are addressed to the non-human world and are not in the service of anthropocentric self-centeredness. They are linked to a survival strategy, but from a different perspective.

Keywords: animism, anthropological linguistics, ethnography of speaking, Finnic languages, pragmatics, beliefs and language 